\title{
Mineralogical investigation of fine clastic rocks from Central Sarawak, Malaysia
}

\author{
Walaa Elnasir Ibrahim ${ }^{1} \cdot$ Ahmed Mohamed Ahmed Salim ${ }^{1} \cdot$ Chow Weng Sum ${ }^{1}$
}

Received: 30 October 2018 / Accepted: 31 July 2019 / Published online: 9 August 2019

(c) The Author(s) 2019

\begin{abstract}
The reduction in the conventional resources and insistent request for hydrocarbons and energy lead us to look forward for the increasing interest in unconventional resources by exploring new technologies for the national economy and local utilization in Malaysia. Upper Mesozoic-Cenozoic is considered the age of Central Sarawak Formations. This paper attempts to evaluate the clay mineralogy, depositional environment, gamma ray evaluation and the relationship between total organic carbon and uranium concentration of the Nyalau, Tatau, Begrih, Liang and Belaga Formation which eventually comprise black shales and mudstones using spectral gamma ray (SGR), field-emission scanning electron microscopy (FESEM), X-ray diffraction (XRD), XRD clay separation and total organic content (TOC\%). The results from SGR indicate that the formations composed mainly of kaolinite, smectite and chlorite. These results are confirmed by XRD, XRD clay separation and FESEM with the presence of illite as a dominant clay mineral component. Based on $\mathrm{Th} / \mathrm{U}$ ratios which vary between 0.42 and 3.95 , the formations are expected to be deposited in the reduced marine environment. Results from calculated API (90.76-233.32 API) reveal the ability of the clay minerals to absorb uranium and thorium through cation exchange capacity. The relationship between TOC\% and $\mathrm{U}$ cross plots also show a significant positive correlation. The presence of high $\mathrm{U}$ concentrations in the formations is possible because of their relatively higher clay contents and the existence of organic matter.
\end{abstract}

Keywords Formations $\cdot$ Spectral gamma ray $(\mathrm{SGR}) \cdot$ Clay minerals $\cdot$ Organic matter $\cdot$ Shale $\cdot$ Mudstone

\section{Introduction}

Shale is a laminated indurated rock. Approximately about $60 \%$ of sedimentary rocks are shale with more than $67 \%$ clay-sized materials deposited in low-energy depositional environments where the fine-grained clay particles fall out of suspension (Jackson et al. 1997). However, fissility is absent in mudstones (Tucker 1991; Blatt 2006). The increasing interest in unconventional resources aided by new technologies is recently gaining attention in Malaysia to explore shale gas potentials for the national economy and local utilization.

Walaa Elnasir Ibrahim

umshamswalaa@gmail.com

Ahmed Mohamed Ahmed Salim

mohamed.salim@utp.edu.my

Chow Weng Sum

chow_wengsum@utp.edu.my

1 Department of Geoscience, Universiti Teknologi PETRONAS, 32610 Seri Iskandar, Tronoh, Perak Darul Ridzuan, Malaysia
There is an emphasis to physical and chemical portray properties such as TOC\%, clay contents and radioactive elements composition and its distribution to understanding their depositional environments. Wherefore, by interpretation of varying gamma ray signatures for non-cored outcrops becomes paramount.

For decades, preliminary investigation in potential hydrocarbon reservoirs consisted of measuring natural gamma radiation to discretize between shale and non-shale interludes, while the spectral gamma ray (SGR) technique are used to subdivide the homogenous marine black shale intervals by fine-scale changes in the distribution of potassium $(\mathrm{K})$, uranium $(\mathrm{U})$ and thorium $(\mathrm{Th})$ that reflected minute mineralogical differences (Fertl and Chilingarian 1990; McGowan 2015). Gamma ray curves have been a valuable tool used to correlate exposures in outcrop to the subsurface (Aigner et al. 1995). It necessitates a field trip implemented to investigate outcrops of black shales and mudstones in central Sarawak, Malaysia. The study covers Nyalau, Tatau, Begrih, Liang and Belaga Formations in Central Sarawak, Malaysia (Fig. 1). 
Fig. 1 Location map of the study area modified after Iqbal et al. (2017)

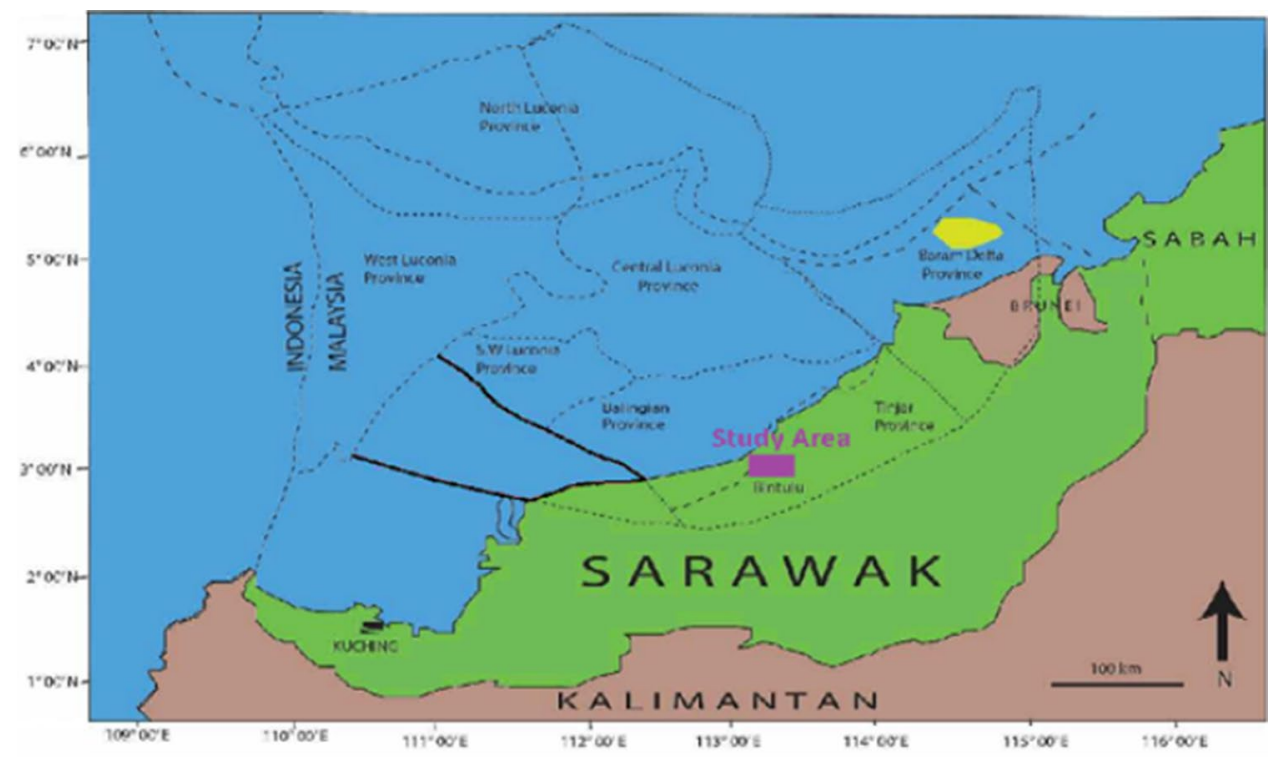

Sarawak Basin has an extensive prevalence of shale outcrops. Black shales are deposited under anaerobic conditions and in very slow-moving water. They are deposited in various depositional environments, which include lakes and lagoonal deposits, river deltas, floodplains and offshore. Late Eocene to Recent age is considered the age of Sarawak Basin (Madon 1999), and another suggestion by Wolfenden (1960) was deposited during Oligocene-Early Miocene times. It is considered as a foreland basin which is developed from the collision of the West Borneo basement and Luconia block through Eocene age (Madon et al. 2013). SGR have been used effectively by various researchers to characterize the mineralogy and sedimentology of outcrops (Svendsen and Hartley 2001). Log trends/patterns and electrofacies developed from the gamma ray log responses, which will allow the characterization of the depositional environment in different facies (Siddiqui et al. 2013) of the various outcrops and provide information about minerals and clay types. Secondly, from the spectral gamma ray logs, gamma radiation was counted within specific energy ranges. These counts were computed and then assigned to each prime radioactive source. Afterward, potassium-thorium (K-Th) cross plot was constructed to identify the clay mineral associations as well as the identification of micas and feldspar. In addition, a $\mathrm{Th} / \mathrm{U}$ ratio was generated to link depositional environment to geochemical composition. $\mathrm{Th} / \mathrm{U}$ and $\mathrm{Th} / \mathrm{K}$ cross plots were used to evaluate compositional changes.

Typically, the presence of fine clastic deposits or clayrich rock formation, such as shale, claystone, mudstone, indicates high response of gamma ray, while the existence of coarse-grained sandstone and carbonate rock indicates low response of gamma radiation which displays higher water-transmitting capacity (Schon 2011; Chou et al. 2014). The distribution of $\mathrm{U}, \mathrm{Th}$ and $\mathrm{K}$ in sedimentary rocks and minerals is controlled by the main factors which are the origin of the clastic components and the chemical and physical stability of these components in the sedimentary environment (Nielsen et al. 1987). The ideal black shale is petrophysically described as a sedimentary rock with very high gamma ray activity, high resistivity, and low bulk density. Moreover, sedimentary rocks like shales show a higher concentration of thorium (Th), uranium (U) and $\mathrm{Th} / \mathrm{U}$ ratio compared with igneous rocks (Larsen and Gottfried 1960). The thorium content of shales differs considerably less than the uranium content (Adams and Weaver 1958).

Previous studies on the formations put emphasis on more evaluation of sandstone reservoir properties, such as petrography, grain size and the connectivity of the various sandstone lithofacies in Bintulu and Miri, to create a 2-D intermediate-scale model from outcrop in Nyalau Formation (Siddiqui et al. 2014). The Nyalau Formation was identified as the major source rock unit and was expected to be extensively distributed across the Sarawak Basin (Togunwa et al. 2015). The oldest textural characteristics of shallow marine sandstones of the Nyalau Formation (well-exposed outcrops) from Oligocene-Middle Miocene composed of subordinate shale and massive sandstone that were deposited under shallow water marine conditions, (Siddiqui et al. 2016). Furthermore, Iqbal et al. (2017) assessed the Nyalau Formation on the basis of measurements for porosity and permeability in different facies, and the impact of pore throat size on porosity and permeability. Moreover, Baioumy et al. (2018) studied inorganic and organic of the Paleogene-Neogene coals and their related black shales to investigate their origin, depositional environment and hydrocarbon potential in different formations includes Nyalau, Begrih and Liang 
Formation, and they found the black shale-related to coal as another source rock it can be considered.

The Liang Formation consists of shales, sandstones, conglomerates and abundant lignite, which were deposited during middle Miocene to upper Miocene in the environment of predominantly coastal plain with some influences of shallow marine in the northern part of the outcrops (Mat-Zin 1996). The lithology of the Belaga Formation consists of thin-tothick, fine- to medium-grain interbedded sandstone with argillaceous rock, mudstone facies with dark gray carbonaceous shale intercalated with fine-grained silty sand in deep marine along Bintulu Sibu road (Sia and Abdullah 2012).

All previous investigation on the formations focuses mainly on sandstone reservoir properties, tectonic history, the origin and potentiality of the coal as the source rock. There are no comprehensive outcrops study on clay mineral identification and depositional environment of black shale and mudstone formations by SGR techniques. This paper attempts to evaluate clay mineralogical composition to determine depositional environment of the formations black shale and mudstone and the relationship between TOC\% and U concentrations in the onshore formations in Central Sarawak Basin using SGR.

Laboratory analyses for shale and mudstone evaluations are ubiquitous over the world for the assessment of clay minerals. Furthermore, this study utilizes the use of SGR counts where the response of radioactive isotopes of potassium $(\mathrm{K})$, uranium $(\mathrm{U})$ and thorium $(\mathrm{Th})$ is applied and interpreted with the existence of field-emission scanning electron microscopy (FESEM), X-ray diffraction and (XRD) and clay mineral separation methods.

Individual fractions of radioactive elements uranium; thorium and potassium, and their ratios are measured using SGR tool. Various cross plots (Th (vs.) K and U (vs.) TOC\%) for the formations are constructed.

\section{Materials and methods}

Onshore sixty-eight samples from five formations (Nyalau, Tatau, Begrih, Liang and Belaga) obtained from 46 outcrops were taken from Central Sarawak. The study focused on fine clastic rocks (shale and mudstone) samples acquired from these formations. SGR readings from the outcrops were taken and recorded by using gamma ray surveyor II. Gamma surveyor is a new group of multi-channel gamma ray spectrometers and dose rate meters designed for measurements of natural and artificial isotopes in ground, boreholes and laboratories. The measurement workflow: (i) switch on the instrument and select spectral gamma ray; (ii) select the measuring mode spectrum and assay in order to measure the concentrations of $\mathrm{K}, \mathrm{U}, \mathrm{Th}(\%, \mathrm{ppm}, \mathrm{ppm})$ and natural gamma dose rate $(\mathrm{nGy} / \mathrm{h})$. (iii) place the equipment on a smooth surface in the outcrop; (iv) select a measuring time of 3 min and take measurement; (v) take note of the readings after the $3 \mathrm{~min}$. The outcrops of the study area located coordinates ranging between longitudes E112 $06^{\prime} 51.6^{\prime \prime}-\mathrm{E} 113^{\circ} 05^{\prime} 28.8^{\prime \prime}$ and latitudes $\mathrm{N} 02^{\circ} 22^{\prime} 35.8^{\prime \prime}-\mathrm{N} 03^{\circ} 11^{\prime} 34.1^{\prime \prime}$. The mineralogical analysis was obtained by XRD, and Powder X-ray patterns were generated by Philips-P Analytical X'pert Pro powder diffractometer using $\mathrm{Cu} \mathrm{K} \alpha$ radiation, and an automatic divergence, an anti-scattering slit and a secondary graphite monochromator with a scintillation counter. The diffraction data were listed from 3 to $602 \theta$ with a step width of $0.02^{\circ}$ and a counting time of $4 \mathrm{~s}$ per step.

The clay minerals were separated from the bulk shale samples using clay mineral separation methods to extract the fraction of the sediments $<2 \mu \mathrm{m}$ from the samples. Samples were carefully washed with distilled water to remove the remains of the cuttings rocks and to be cleaned. The wet samples were put in plastic bottles, submerged with distilled water and then fixed to the samples shaker for disintegration. Ultrasonic treatment was sometimes used for highly indurated samples. Distilled water was added to the samples until a hydraulic conductivity of about $<50-60 \mu \mathrm{S}$ (microsiemens) was reached. The suspension was then centrifuged for $2 \mathrm{~min}$ with a speed of 2000 rounds/minute. The fine silt particles will eventually settle, while the less than a $2-\mu \mathrm{m}$-size fraction will remain in suspension. The suspension was filtered through ceramic filters to get rid of the water and to gather the clay particles. The filtration product was collected in dishes and kept in an oven at $50{ }^{\circ} \mathrm{C}$ for the analytical purposes; from the wet clay fraction $(<2 \mu \mathrm{m})$ oriented mounts were prepared on glass slides to obtain the basal reflection orientation. The prepared glass slides were kept in a desiccator for $24 \mathrm{~h}$ to dry and then taken for airdried measurements. The character set of d-spacing generated in a typical X-ray scan provides a unique "fingerprint" of the mineral or minerals present in the sample. The clay minerals were identified from their basal reflections determined from the XRD pattern, after (1) air drying (normal), (2) glycolation for $48 \mathrm{~h}$ under $50^{\circ} \mathrm{C}$, (3) heating to $350{ }^{\circ} \mathrm{C}$ for $1 \mathrm{~h}$ and lastly (4) heating to $550^{\circ} \mathrm{C}$ for $4 \mathrm{~h}$. Then the four runs were subjected to several analytical steps through two computers programmed which are Philips X'Pert Organiser and X'Pert Plus.

Small chips of core samples were obtained by obligingly breaking the rock with a rock chopper. Subsequently, the samples were coated with a conductive material such as gold. The coating of the sample is needed to make the samples conductive and get an apparent image of an insulating material. The coated samples were placed in the chamber and vacated ultimately. The sample was scanned by using field-emission scanning electron microscopy (FESEM) at variable magnifications after those FESEM micrographs were interpreted, and consequently, the EDX spectrum

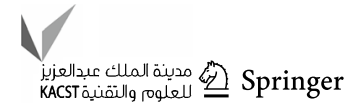


points were also carried out by using SEM Petrography Atlas (Welton and Atlas 1984).

TOC content was carried out using Analytikjena HT 1300 Solids Carbon Analyzer in Universiti Teknologi PETRONAS. Total organic carbon (TOC) $\%$ measurements were obtained using the direct method proposed by Dow and Pearson (1975). The crushed samples were weighed and treated with $10 \%$ hydrochloric acid $(\mathrm{HCl})$ to take off the inorganic carbon and carbonate minerals.

\section{Results and discussion}

\section{Clay mineral identification}

The determined SGR activity concentrations are presented in Table 1. The Th, $\mathrm{U}$ and $\mathrm{K}$ generated values from SGR of Nyalau, Begrih and Liang show close range, with the Tatau and Belaga generating higher radioactive emission. A total of 51 SGR data were collected (Table 1), and the Th/K ratio was calculated and the dominant of clay minerals were determined by using Fertl (1979) in Table 2. Nyalau Formation (11.15-22.25) ppm/\%, Tatau Formation (6.75-19.36) ppm/\%, Begrih Formation (13.79-19.41) ppm/\%, Liang Formation (10.09-17.03) ppm/\% and Belaga Formation $(4.58-25) \mathrm{ppm} / \%$ reference a general orientation of $\mathrm{Th} / \mathrm{K}>10>3.5$ which is foretelling of mixed-layer clays, in which smectite (montmorillonite), kaolinite and chlorite can be deduced from the mineralogical chart as seen in Fig. 2.

$\mathrm{Th} / \mathrm{K}$ plots identified smectite, chlorite and kaolinite clay minerals with no presence of illite. These interpretations for the determination of clay type using SGR are limited. Hence, clay identification is confirmed with the use of XRD, XRD clay separation methods and FESEM. Bulk XRD presents the general trend of the existence of minerals which includes quartz, clay minerals, feldspars, carbonates and pyrite. The most predominant clay minerals in most analyzed samples from all the formations with XRD clay separation are illite, kaolinite, smectite, chlorite and illite in mixed layer with smectite, respectively. FESEM micrograph showed the clay flakes of the kaolinite, illite, smectite and chlorite clay minerals. EDX analysis confirmed the most presence of these
Table 2 Clay minerals classification based on $\mathrm{Th} / \mathrm{K}(\mathrm{ppm} / \%)$ (Klaja and Dudek 2016)

\begin{tabular}{lll}
\hline No. & Th/K $(\mathrm{ppm} / \%)$ & Minerals \\
\hline 1 & $<0.6$ & Feldspars \\
2 & $0.6-1.5$ & Glauconite \\
3 & $1.5-2.0$ & Micas \\
4 & $2.0-3.5$ & Illite \\
5 & $>3.5$ & Mixed-layer clays \\
6 & 10 and above & Kaolinite and chlorite \\
\hline
\end{tabular}

clay mineral elements (Fig. 3. Nyalau. F) and (Fig. 4. Tatau. F).

The Central Sarawak Formations is predominant with illite, kaolinite, smectite, chlorite and illite in mixed layer with smectite, respectively. The use of mixed-layer illite/smectite $(\mathrm{I} / \mathrm{S})$ as a geothermometer and indicator of thermal maturity is based on detailed studies in shale diagenesis that is described in Gulf Coast (Hower et al. 1976; Hoffman and Hower 1979). Many authors report the transformation of clay minerals during diagenesis is from montmorillonite (smectite) to mixedlayer montmorillonite/illite to illite (Hower et al. 1976; Jiang 2012). During early diagenesis, maturity of the source rock is quite low and smectite bias the percentage of illite-smectite mixed-layer clays. With the thermogenic conditions and timing, clay minerals loose pore water and little oil is generated during this period. When more smectite are converted to more illites present in mixed-layer clay, cracking of more hydrocarbons form dry gas (Jiang 2012). The shale and mudstone of the formations by the percentage of illite may diagenetically mature to generate oil and gas. The high maturity for the gas window usually present in shales which have most of the smectite content converted to illite (Gasparik et al. 2013). Thus, the shales and mudstone of the formations it may have more gas feasible with estimation to the type of clay mineral.

\section{Depositional environment}

Th-to-U ratio has influential effect on the evaluation of depositional environment (Klaja and Dudek 2016). The ratios of thorium to uranium in sedimentary rocks vary from 0.02

Table 1 Value of potassium, uranium and thorium concentration with $\mathrm{Th} / \mathrm{U}$ ratio, $\mathrm{Th} / \mathrm{K}$ ratio and the gamma ray in API obtained from the formations sample

\begin{tabular}{lcccccc}
\hline Formation & $\mathrm{K} \%$ range & $\mathrm{U}(\mathrm{ppm})$ range & Th $(\mathrm{ppm})$ range & Th/U range & Th/K $(\mathrm{ppm} /)$ range & GR $(\mathrm{API})$ range \\
\hline Nyalau & $0.56-0.98$ & $12.87-18.90$ & $9.59-12.46$ & $0.57-0.85$ & $11.15-22.25$ & $121.19-169.23$ \\
Tatau & $0.60-2.53$ & $4.70-22.56$ & $8.89-18.76$ & $0.42-3.59$ & $6.75-19.36$ & $79.81-197.660$ \\
Begrih & $0.58-0.78$ & $12.90-13.95$ & $10.48-14.17$ & $0.80-1.03$ & $13.79-19.41$ & $124.63-135.91$ \\
Liang & $0.59-0.99$ & $9.4-14.60$ & $9.50-11.94$ & $0.73-1.06$ & $10.09-17.03$ & $94.42-138.160$ \\
Belaga & $0.48-3.95$ & $2.91-11.62$ & $9.93-22.07$ & $1.03-3.95$ & $4.58-25.00$ & $64.07-157.100$ \\
\hline
\end{tabular}



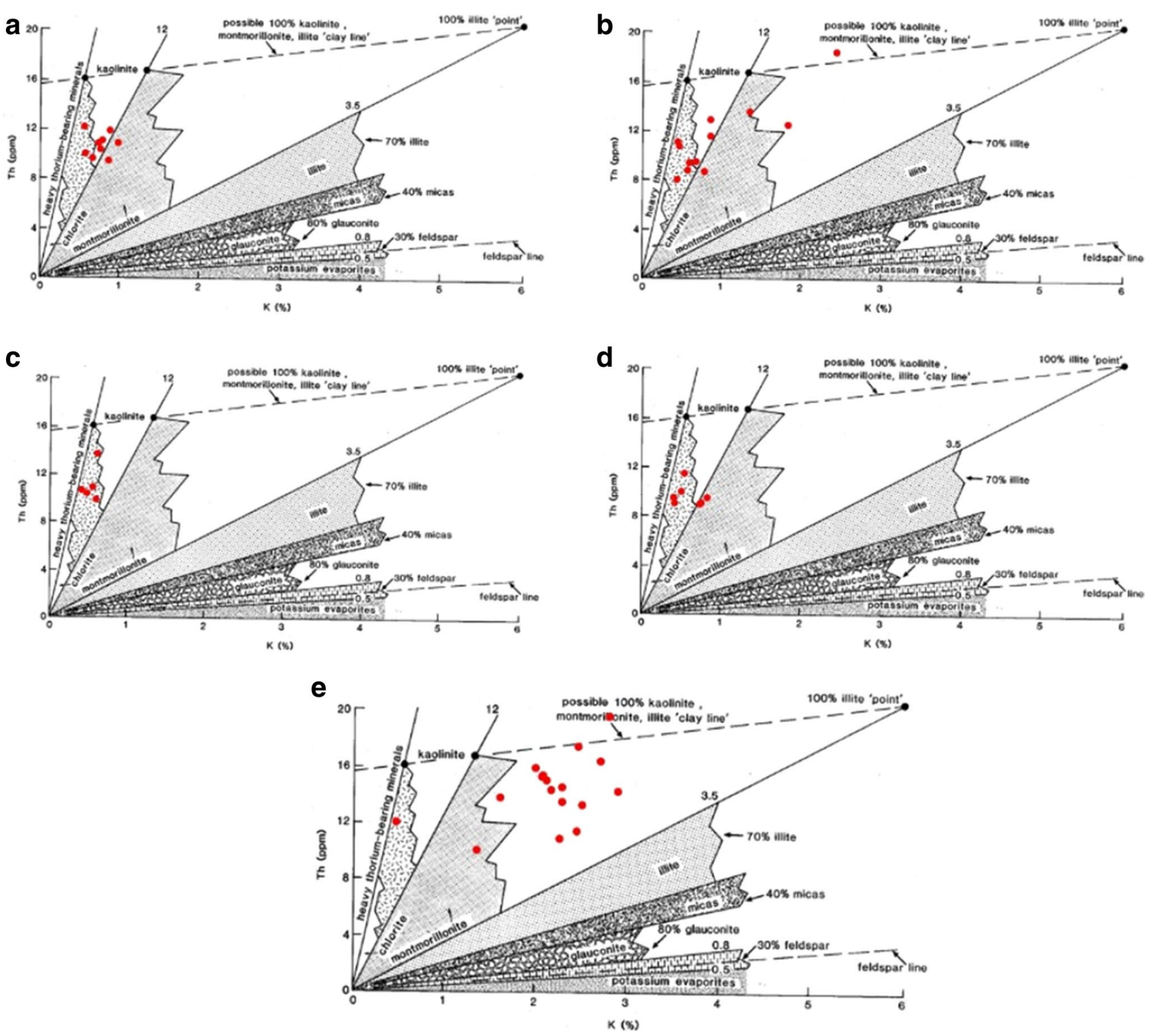

Fig. 2 Mineralogical charts of Th/K ratio cross plots for identification of clay minerals. a Nyalau Formation, b Tatau Formation, $\mathbf{c}$ Begrih Formation, d Liang Formation and e Belaga Formation (Quirein et al. 1982)

to over 21 . The $\mathrm{Th} / \mathrm{U}$ ratios in many continental oxidized deposits are above 7 , whereas most marine deposits have rates considerably less than 7 (Adams and Weaver 1958; Klaja and Dudek 2016). Another specified classification of the $\mathrm{Th} / \mathrm{U}$ ratio as indicator for depositional environment by Klaja and Dudek (2016), when the $\mathrm{Th} / \mathrm{U}<7$ but $>2$ indicate marine sediments, grey and green shales while $\mathrm{Th} / \mathrm{U}<2$ indicate reducing deep marine environment generative of black shales.

Various prior workers have proposed that thorium and uranium concentrations or $\mathrm{Th} / \mathrm{U}$ ratios might serve as critical indicators of sedimentary processes or environments. Koczy (1949) has proposed a small analysis that the $\mathrm{Th} / \mathrm{U}$ ratio should reduce as the distance from the shore is amplified. Then, the ratios of thorium to uranium vary with the difference in sedimentary processing and depositional environment. The $\mathrm{Th} / \mathrm{U}$ ratios of the formations samples (Table 1) vary between 0.42 and 3.95, which indicates possible reducing deep marine black shales with gray and green shales especially in Tatau and Belaga Formations.

\section{Gamma ray calculation}

Based on the formula in Elsinger and Pevear (1988), Eq. (1) has been used to calculate gamma ray in API and results are presented in Table 1: 

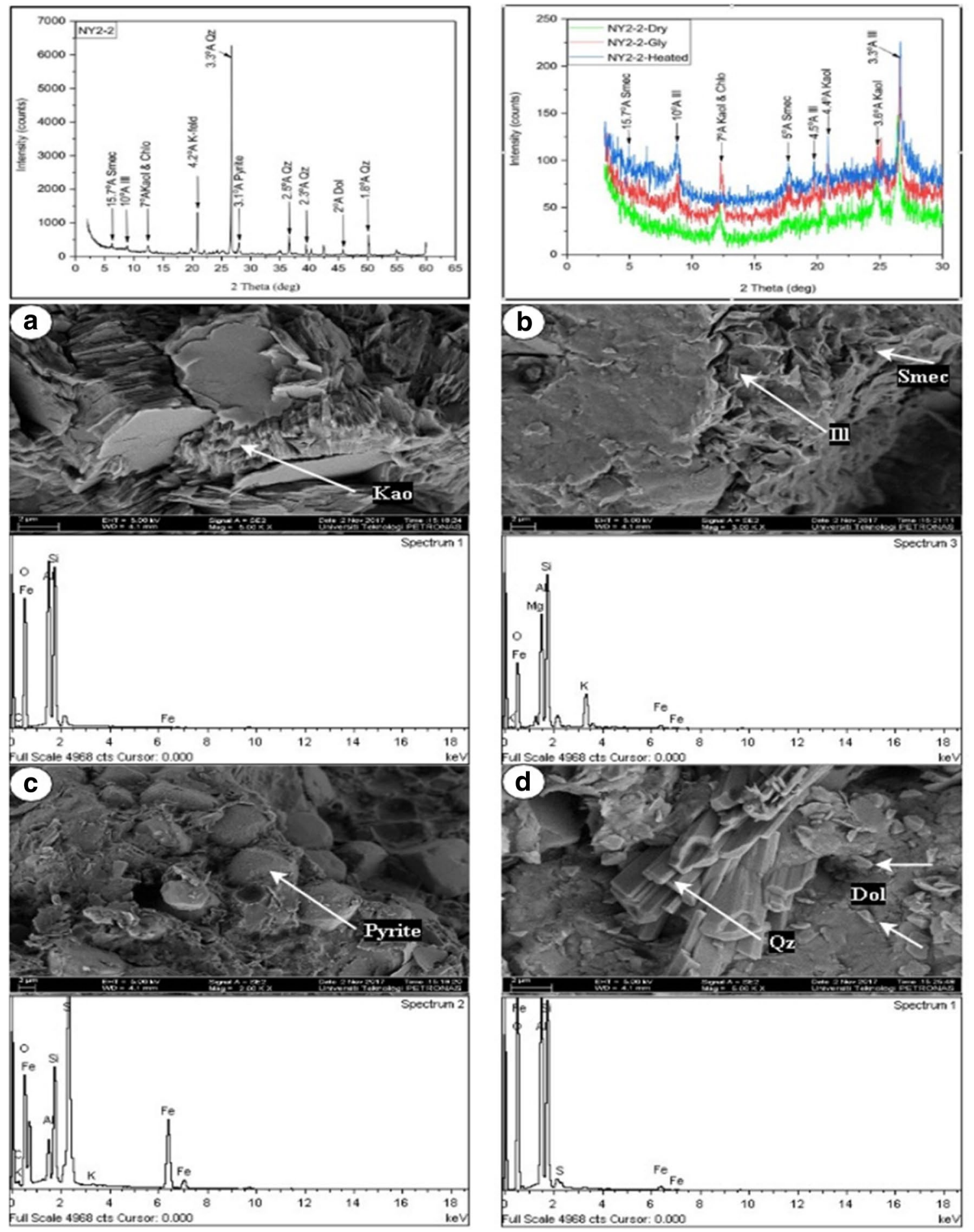

Fig. 3 XRD, XRD clay separation and FESEM micrograph for Nyalau Formation showing the main mineral components in the shale and mudstone samples and their energy-dispersive X-ray (EDX) spec-

$\mathrm{API}=16.5 \mathrm{~K}(\%)+7.48 \mathrm{U}(\mathrm{ppm})+4 \mathrm{Th}(\mathrm{ppm})$

The emission of the gamma rays from shales more than other sedimentary rocks, like sandstone, coal, gypsum, trum showing the main elements $\mathbf{a}$ Kao $=$ kaolinite, $\mathbf{b}$ Ill $=$ illite and Smec $=$ smectite, $\mathbf{c}$ pyrite, $\mathbf{d} \mathrm{Qz}=$ quartz and Dol=dolomite

salt and carbonate, is due to the presence of radioactive potassium as a common component in the clay content of shales and can be attributed to the ability of clays to absorb uranium and thorium via cation exchange capacity. 

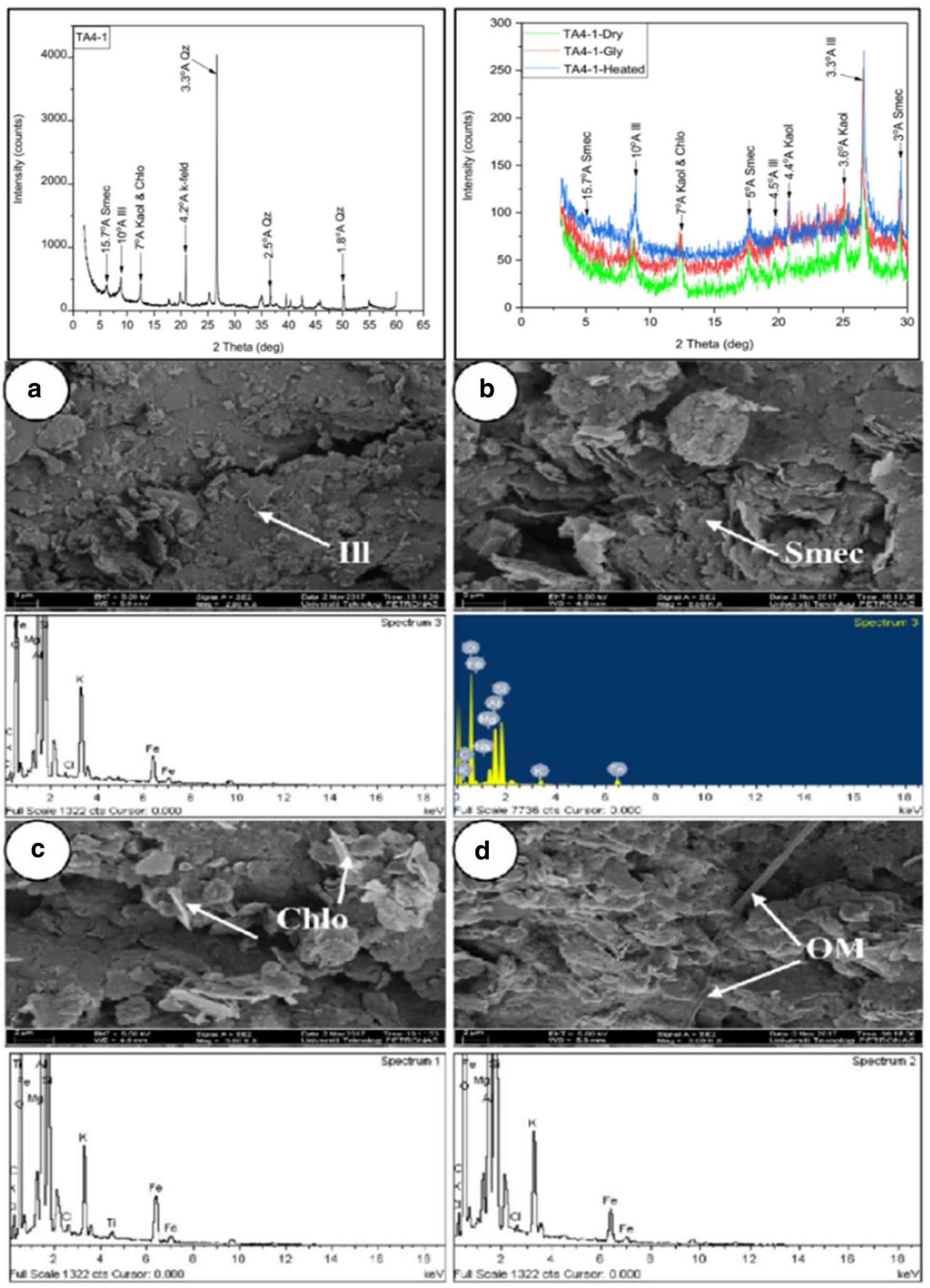

Fig. 4 XRD, XRD clay separation and FESEM micrograph for Tatau Formation showing the main mineral components in the shale and mudstone samples and their energy-dispersive X-ray (EDX) spec- trum showing the main elements a Ill=illite, $\mathbf{b}$ Smec=smectite, $\mathbf{c}$ Chlo $=$ chlorite and $\mathbf{d} \mathrm{OM}=$ organic matter 
Table 3 TOC\% range and classification for the Formations (Peters and Cassa 1994)

\begin{tabular}{lll}
\hline Formation & Range of TOC $\%$ & TOC\% classification \\
\hline Nyalau & $0.26-1.47$ & Poor-good \\
Tatau & $0.14-0.82$ & Poor-fair \\
Begrih & $0.59-1.80$ & Fair-good \\
Liang & $0.32-1.62$ & Poor-good \\
Belaga & $0.04-1.63$ & Poor-good \\
\hline
\end{tabular}

The values of the gamma ray (GR) in these formations range from 64.07 to 197.66 API (Table 1). The lowest value is recorded in Belaga Formation and the highest value in Tatau Formation, which is considered as high estimated value and may be due to the organic matter existence which generates a reduction environment that results in the precipitation of uranium and subsequent high activity of gamma ray.

\section{Relationship between total organic carbon (TOC)\% and $U$ concentration}

The relationship between total organic carbon (TOC) and uranium concentration has previously been documented worldwide by different authors (Lüning and Kolonic 2003; Correia 2012). The TOC values range from 0.04 to $1.80 \%$; the results interpreted according to Peters and Cassa (1994) as shown in Table 3 indicate that shale and mudstone samples
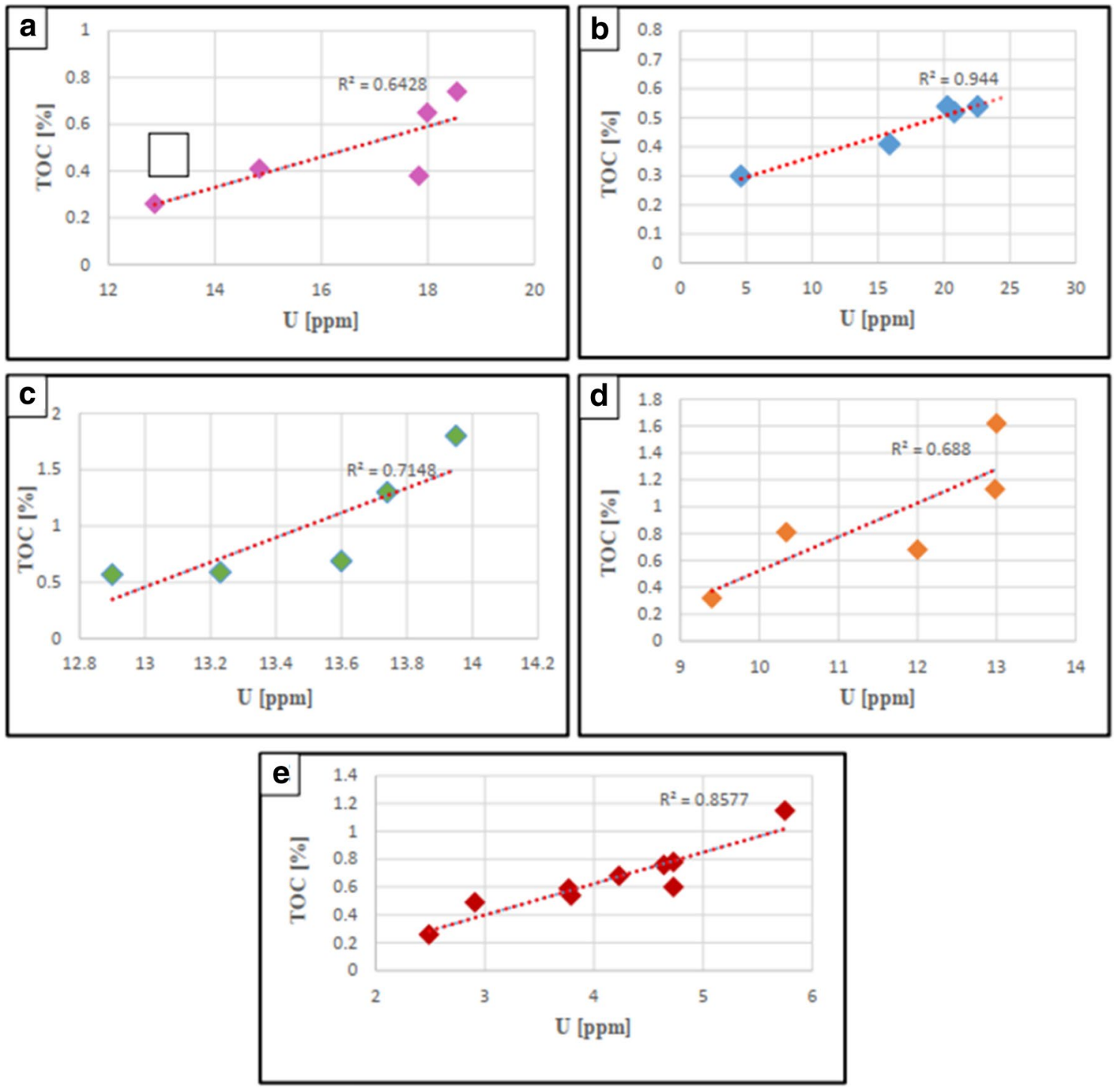

Fig. 5 TOC\%/U cross plots of mudstone and shale samples in different formations a Nyalau Formation, b Tatau Formation, $\mathbf{c}$ Begrih Formation, d Liang Formation and e Belaga Formation 
have poor-to-good hydrocarbon generative potential. The Begrih Formation reveals highest value for TOC\% (1.80\%), attributed to the presence of coal within stratigraphic succession. The relationship between TOC $\%$ and $U$ can be expressed by the equations (TOC\% $=0.0652 * \mathrm{U}-0.5829$ ), $(\mathrm{TOC} \%=0.0141 * \mathrm{U}+0.2246), \quad(\mathrm{TOC} \%=1.0957 *$ $\mathrm{U}-13.785),(\mathrm{TOC} \%=0.252 * \mathrm{U}-1.9973)$ and $(\mathrm{TOC} \%=$ $0.2254 * \mathrm{U}-0.2775)$ for Nyalau, Tatau, Begrih, Liang and Belaga, respectively.

There is a good correlation between the organic matter content determined in laboratory and U concentration from SGR cross plots (Fig. 5) in different formations. The higher $U$ (ppm) concentration in the formations could be ascribed to relatively high organic matter and clay contents present.

\section{Conclusion}

Integrated study of mudstone and black shale from the Nyalau, Tatau, Begrih, Liang and Belaga Formations Central Sarawak between Sibu to Miri Zones was carried out by using spectral gamma ray method.

The cross plots of Th (vs.) K radiometric analysis of the formations interpreted as dominant in kaolinite, smectite and chlorite clay minerals with no presence of illite. XRD clay separation obtained indicate that illite, kaolinite, smectite, chlorite and illite in mixed-layer with smectite are the dominant clay minerals in the formation, respectively, which also validated from FESEM. That indicate that SGR method is a quick method, and it has to be confirmed by XRD and FESEM.

Moreover, $\mathrm{Th} / \mathrm{U}$ ratios evidenced to be convenient when used as indirect means for depositional environments suppose that the depositional environment of the mudstone and black shales of Central Sarawak Formations are reduced marine depositional environments range from grey to black shales with the data having $\mathrm{Th} / \mathrm{U}$ ratio in the range of $0.42-3.95$. High values of the gamma ray (GR) in these formations range from 90.76 to 233.32 API which has indicated the ability of clays to absorb uranium and thorium through cation exchange capacity. The cross plots of TOC\%/U reveal a considerable positive correlation with the organic matter evolution. The presence of high $U$ concentration in the formations is possible because of their relatively higher clay contents and the existence of organic matter.

Acknowledgements The author would like to thank Universiti Teknologi PETRONAS for providing the Graduate Research Assistantship Scheme (GRA) under a shale gas project (PRF) and laboratory facilities.
Open Access This article is distributed under the terms of the Creative Commons Attribution 4.0 International License (http://creativeco mmons.org/licenses/by/4.0/), which permits unrestricted use, distribution, and reproduction in any medium, provided you give appropriate credit to the original author(s) and the source, provide a link to the Creative Commons license, and indicate if changes were made.

\section{References}

Adams JA, Weaver CE (1958) Thorium-to-uranium ratios as indicators of sedimentary processes: example of concept of geochemical facies. AAPG Bull 42(2):387-430

Aigner T, Schauer M, Junghans WD, Reinhardt L (1995) Outcrop gamma-ray logging and its applications: examples from the German Triassic. Sed Geol 100(1):47-61

Baioumy H, Salim AMA, Arifin MH, Anuar MNA, Musa AA (2018) Geochemical characteristics of the Paleogene-Neogene coals and black shales from Malaysia: implications for their origin and hydrocarbon potential. J Nat Gas Sci Eng 51:73-88

Blatt H, Tracy R, Owens B (2006) Petrology: igneous, sedimentary, and metamorphic. Macmillan, New York

Chou P-Y, Hsu S-M, Chen P-J, Lin J-J, Lo H-C (2014) Fracturedbedrock aquifer studies based on a descriptive statistics of welllogging data: a case study from the Dajia River basin, Taiwan. Acta Geophys 62(3):564-584

Correia G (2012) Outcrop gamma-ray spectrometry: applications to the Sinemurian-Pliensbachian organic-rich facies of the Lusitanian Basin (Portugal). J Iberian Geol 38(2):373-388

Dow WG, Pearson DB (1975) Organic matter in Gulf Coast sediments. In: Offshore technology conference Dallas, Texas, USA

Elsinger E, Pevear D (1988) Clay minerals for petroleum geologist and engineers. Society of Economic Paleontologists, Mineral short course-Notes 22

Fertl WH (1979) Gamma ray spectral data assists in complex formation evaluation. Log Analysts 20(5):3-37

Fertl WH, Chilingarian GV (1990) Hydrocarbon resource evaluation in the Woodford shale using well logs. J Pet Sci Eng 4(4):347-357

Gasparik M, Ghanizadeh A, Gensterblum Y, Krooss BM (2013) "Multi-temperature" method for high-pressure sorption measurements on moist shales. Rev Sci Instrum 84(8):085116

Hoffman J, Hower J (1979) Clay mineral assemblages as low grade metamorphic geothermometers: application to the thrust faulted disturbed belt of Montana, USA. Soc Econ Paleontal Mineral Spec Publ 26:55-79

Hower J, Eslinger EV, Hower ME, Perry EA (1976) Mechanism of burial metamorphism of argillaceous sediment: 1. Mineralogical and chemical evidence. Geol Soc Am Bull 87(5):725-737

Iqbal MA, Salim AMA, Baioumy HM, Gaafar GR, Wahid A (2017) Porosity, permeability and pore throat size distribution of Nyalau Formation, Bintulu Area, Sarawak Basin, Malaysia. J Appl Environ Biol Sci 7(10):151-158

Jackson RB, Mooney HA, Schulze E-D (1997) A global budget for fine root biomass, surface area, and nutrient contents. Proc Nat Acad Sci 94(14):7362-7366

Jiang S (2012) Clay minerals from the perspective of oil and gas exploration. In: Clay minerals in nature-their characterization, modification and application. IntechOpen. https://doi.org/10.5772/47790

Klaja J, Dudek L (2016) Geological interpretation of spectral gamma ray (SGR) logging in selected boreholes. Nafta-Gaz 72(1):3-14

Koczy FF (1949) The thorium content of the Cambrian alum shales of Sweden. Norstedt, Stockholm

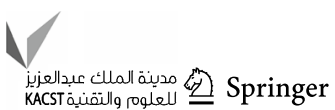


Larsen ES, Gottfried D (1960) Uranium and thorium in selected suites of igneous rocks. Am J Sci 258-A:151-169

Lüning S, Kolonic S (2003) Uranium spectral gamma-ray response as a proxy for organic richness in black shales: applicability and limitations. J Pet Geol 26(2):153-174

Madon MBH (1999) The petroleum geology and resources of Malaysia. Petroleum Nasional berhad (PETRONAS), Kuala Lumpur

Madon M, Kim CL, Wong R (2013) The structure and stratigraphy of deepwater Sarawak, Malaysia: implications for tectonic evolution. J Asian Earth Sci 76:312-333

Mat-Zin I (1996) Tertiary tectonics and sedimentation history of the Sarawak basin, east Malaysia. PhD theses, Durham University

McGowan EM (2015) Spectral gamma ray characterization of the Elko Formation, Nevada - a case study for a small Lacustrine Basin, Colorado State University. Libraries

Nielsen BL, Løvborg L, Sørensen P, Mose E (1987) Gamma-ray analysis for $\mathrm{U}$, Th and $\mathrm{K}$ on bulk cutting samples from deep wells in the Danish subbasin and the north German basin. Report Ris $\varnothing-$ M-2646 85

Peters KE, Cassa MR (1994) Applied source rock geochemistry: chapter 5-part II. Essential elements. In: Magoon LB, Dow WG (eds) The petroleum system - from source to trap, vol 60. American Association of Petroleum Geologists, Memoir, pp 93-120

Quirein JA, Gardner JS, Watson JT (1982) Combined natural gamma ray spectral/litho-density measurements applied to complex lithologies. In: SPE annual technical conference and exhibition. Society of Petroleum Engineers

Schon J (2011) Physical properties of rocks: a workbook. Handbook of petroleum exploration and production. Elsevier, London

Sia S-G, Abdullah WH (2012) Enrichment of arsenic, lead, and antimony in Balingian coal from Sarawak, Malaysia: modes of occurrence, origin, and partitioning behaviour during coal combustion. Int J Coal Geol 101:1-15

Siddiqui NA, EL-Ghali MA, bin Abd Rahman AH, Mijinyawa A, BenAwuah J (2013) Depositional environment of shallow-marine sandstones from outcrop gamma-ray logs, Belait Formation,
Meragang Beach, Brunei Darussalam. Res J Environ Earth Sci 5(6):305-324

Siddiqui NA, Rahman AHA, Sum CW, Mathew MJ, Menier D (2014) Facies characteristics and static reservoir connectivity of some siliciclastic tertiary outcrop successions in Bintulu and Miri, Sarawak, East Malaysia. In: Proceedings of the international conference and exhibition of American Association of Petroleum Geologist (AAPG). Istanbul, Turkey

Siddiqui NA, Rahman AHA, Sum CW, Mathew MJ, Menier D (2016) Onshore sandstone facies characteristics and reservoir quality of Nyalau Formation, Sarawak, East Malaysia: an analogue to subsurface reservoir quality evaluation. Arab J Sci Eng 41(1):267-280

Svendsen JB, Hartley NR (2001) Comparison between outcrop-spectral gamma ray logging and whole rock geochemistry: implications for quantitative reservoir characterisation in continental sequences. Mar Pet Geol 18(6):657-670

Togunwa OS, Abdullah WH, Hakimi MH, Barbeito PJ (2015) Organic geochemical and petrographic characteristics of Neogene organicrich sediments from the onshore West Baram Delta Province, Sarawak Basin: implications for source rocks and hydrocarbon generation potential. Mar Pet Geol 63:115-126

Tucker M (1991) Sedimentary petrology, an introduction to the origin of sedimentary rocks. Blackwells, Oxford

Welton J, Atlas SP (1984) SEM Petrology Atlas. In: American association of petroleum geologists methods in exploration series. US Chevron Co

Wolfenden EB (1960) The geology and mineral resources of the lower Rajang Valley and adjoining areas, Sarawak. Geological Survey Department, British Territories

Publisher's Note Springer Nature remains neutral with regard to jurisdictional claims in published maps and institutional affiliations. 